\title{
The Impact of Information Society and Cyber-Culture in Greek Tourism Phenomenon
}

\author{
Maria MANOLA \\ University of West Attica, Athens, Greece \\ marmanola60@gmail.com
}

\begin{abstract}
First, in this paper we will investigates the influence of one of the most important Greek film directors, Angelopoulos, in all national, European and worldwide tourism thru the eyes of cinema camera and Greek cyber-culture. Initially, his award-winning action and the content of his most important work, has always been united with Greece promotion and touristic development. The paper traces how, in the context of information society, his filmography can be an example of good practice for touristic promotion and development and how this kind of cinematography can be a more dynamic section of Greek touristic economy. Second, this paper aims to investigate how ancient drama which flourished in Greek antiquity still represents a portal of touristic attraction and development. Ancient Greek tragedians as well as Aristophanes' comedies magnetize and attract tourists and students from Europe and the whole world. In addition, touristic destinations where tragedy flourished have a huge number of views from tourists. Finally, we present a case study that analyzes the meaning of literary tourism and examines the prospects of its development in Greece. Through conceptual analyzes in two examples it attempts to present the wealth of literature in regard to the style of writing, values and meanings. The aim of the study is to examine the ways that will help the development of tourism through literature as well as to attract potential tourists to these island destinations.
\end{abstract}

Keywords: Information society, Cyber-Culture, Filmography, Touristic economy, Publicity, literary tourism.

\section{Introduction}

The movie industry has a huge impact on tourism. The movies have an important role in promoting culture, religion, social relationships and landscapes of a country, region or city. This is true also for Greece, were there are numerous movies that promotes this country. The specific impact of cinematography and literature on tourism could be measured by netnography [47]. The influence of the Internet on the spheres of human existence is felt today, including on a cultural level, generating what literature calls cyber-culture. Thus, information and communication technology, as the foundation of the knowledge-based information society, makes its presence and influence felt in the sphere of tourism as well. Thus, the magnitude of the tourist phenomenon in Greece is manifested through the tools of cyber-culture, of which a particular place is the Greek cinematographic production accessible through ICT. It is obvious that we refer again to netnography.
For example, Angelopoulos has been an important figure of the Greek cinematography. He has been certified as director, scenariographer and producer, [57] as an artistic figure known worldwide for the aesthetics of his films, for the conjecturally of his scripts, plans and the harmony of form and content. In his work, except from the deepest sense easily transmitted to the viewer, he has the only advantage to combine ancient theatre with Brecht's theatre and cinema as well as poetry, music, and painting.

Kiki Dimoula referring to Theodoros Angelopoulos mentions: "his work was incomparable, monumental aesthetically and cinematic. He is a creative intelligence, multitalented and multi-faced man that was spreading dimensions and had the magic ability to embrace the memory, time, poetry, history, ideology and death" [33].

He was awarded many times in Greece and abroad for his huge work and was characterized "as a great figure of the European culture" [44]. Many directors 
admired him as a model in their artistic steps and his work inspired painters like "Annino" [53], who called him «Beekeeper of the Angels». He had the magical ability to describe with poetic philosophy in a world that glorifies and disputes at the same time his personal experience: "children alienated by their father, a country alienated from its heritage and above all the silence around him". Later on, his work changes and attempts a social approach such as immigration, sociological interpretations of the provincial faces and the main actors. In his works starring nature with beauty and its tranquility that is a source of inspiration for the human mind. He plays allegorically between power of mind and the beauty of nature.

This paper has been based on the study of Angelopoulos' filmography along with a basic review of the main characteristics of some of his most important works.

\section{Angelopoulos and tourism promotion}

Through Angelopoulos filmography we can see another face of Greece which is not always promoted by tourist guides or even the state. A gray aspect of after the disasters that the country suffered from the Civil War, in a very melancholic scenery. But even the cloudy skies, abandoned villages and the endless dilapidated streets of the poor province can be a touristic attraction. It is worth to note that the promoting an area through cinema, as is the case with Florina that inspires Angelopoulos, can be an important opportunity for touristic development [37]. In this case can be promoted a different aspect of Greece as a tourism destination that may be unknown with a significant economic benefit [14]. In some cases, also, local festivals can be organized boosting the regional economy sometimes on the occasion of filming a movie [11].

This promotion of Greece can fit into the frame of 'movie induced tourism' and 'television-induced tourism' [6]. Also Vagionis \& Loumioti in [52] support the view that "that movies constitute an important marketing tool which can effectively serve the strategy for promotion of tourism destinations. Landscapes, significant heritage sites, festivals, attractions and historical monuments have quite often been selected as film shooting locations". It is also worth to note that also governments in many cases encourage movie makers to film in their countries promoting this way their culture and landscapes [24].

\section{National Touristic Promotion via Ancient Drama}

Ancient tragedy born in Ancient Greece consists a very important cultural European heritage. From many tragedies written by the great tragic poets it is only pieces of Aeschylos, Sofocles and Euripides that were saved in their totality. Greek tragedy led to Greek comedy and, together these genres formed the foundation upon which all modern theater is based. Greek drama is broadly accepted that culture and especially antiquity has played a most important role in tourism policy development in Greece from early on in comparison with other countries. Ancient architecture combined with cultural events has been one of the major elements of tourism policy. According to Mitchell [24], art and especially modern aspects art such as cinema can be a way of boosting tourism flows in a country.

The combination of ancient theatre performances with archeological areas is one of the most appropriate applications of this approach. Martha \& Kotsaki [20] have supported the view that culture and especially antiquity have played a key role in tourism policy development in Greece from early on and in comparison with other countries. Ancient architecture when combined with cultural events and festivals is a very good way of promoting Greece as tourism destination.

It is also today that are taking place actions of ancient drama (dances and songs), ancient orchesis from ancient tragedies of great tragic in big cities. Through these events it is easily understood that the municipalities are reinforced and that the cities are shown to Greek and foreign tourists as having various parts and aspects of themselves. Athens with its rich cultural heritage can inspire its citizens 
and visitors. Also all over Greece, we can admire ancient Greek drama performances, not so many of them though, and without systematic character towards tourist attraction. All these elements of the Greek cultural treasure, linked to the cyber culture built on the pillars of the information society, give the formidable size of the Greek tourism phenomenon. And its exploitation through ICT-specific instruments can only support and encourage the tourism industry (figure 1).

According to Loukia Martha and Amalia Kotsaki, [20], in their article "'Ancient Greek Drama and its Architecture as a means to reinforce tourism in Greece"' the undeniable cultural interest of the ancient theatre should be combined with a collective approach aiming in the maximization of the tourist product. $\{\ldots .$.$\} . Ancient theatres today, after$ the necessary excavations can host important performances and constitute a network in Greece. The proposed network would have to include archaeological sites with ancient theatres as well as other touristic attractions such as contemporary cultural centers, areas with outstanding natural beauty, thematic museums and religious destinations. Many of our theatres are being restored and some are used in the summer for performances.
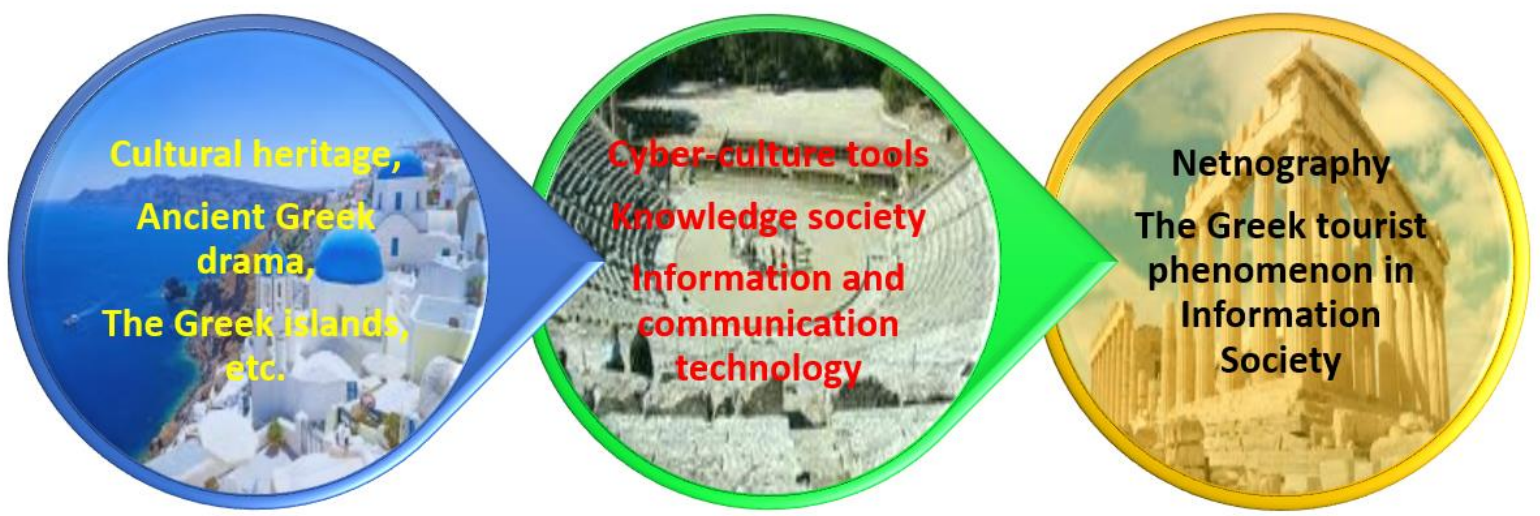

Fig. 1. Netnography - tool of information society and cyber-culture in Greek tourism phenomenon

Touristic industry is aiming to direct tourists knowing how they organize their trips according to legends and myths. The scope is to give ancient Greek drama a larger presence so to better promote touristic theatrical activities and to contribute to the building of theatrical sensibility among the people, by offering them entertainment of a multicultural nature and high aesthetic standards. Ancient Greek drama constitutes the basis of the contemporary European drama and an element of the world cultural heritage, has direct relevance to today's world.

Ancient theatres are not limited but also comprise the Little Theatre of Ancient Epidaurus, spectator capacity of 2000, whilst ancient drama performances also take place at the ancient theatres of Elis near ancient Olympia, Thassos with spectator capacity of 2000, Philippi in Macedonia and Dodona in Epirus, one of the largest and well preserved theatres with spectator capacity 18.000. In August 2013, the recently renovated theatre of ancient Messene in the Peloponnese was added to the list. Some of the most renowned Ancient Greek Theatres, among a list of 125 catalogued theatres, strewn all around Greece are the following:

Theatre of Dionysus built around 500 BC on the south slope of Acropolis the Theatre of Dionysus is the first theatre to have been constructed in the world and the oldest one in Greece. Odeon of Herodes Atticus hosts one of the most important cultural events in Greece, the Athens \& Epidaurus Festival, hosting a great number of theatrical plays, ancient Greek tragedies and comedies and Concerts. Originally built in $161 \mathrm{AC}$, it is called Odeon as it was at first used mainly for music events. Epidaurus Ancient Theatre designed by Polykleitos the Younger in the 4th century BC, it seats up to 15000 spectators 
and it is renowned for its stupendous acoustics whilst Delphi Theatre built with local Parnassus' limestone, Delphi Theatre seats around 5000 spectators and it is found above the Temple of Apollo. According to Greek mythology, Delphi was the site of the Delphic Oracle and it was considered as the navel (center) of the world- the "Omphalos" of the earth! But last but not least, the oldest place which can be called a theatre is situated in

\section{Knossos.}

Many of the Greek theatres are being restored and some are used during summer period for performances. However, there are important perspectives of tourists' attraction for all over the year which is fruitful for local societies. However, there are important perspectives of tourists' attraction for all over the year which is fruitful for local societies.

For this end, there should be certain tourist policy instruments through the development of cultural tourism, the selection of new tourist destinations exploiting new financial and developmental tools and the implementation of new investments of cultural tourism in favor of financed and developmental tools:

- Incorporation to European resources of financing in favor of modernization of cultural centers and theatres in order to be compatible to ancient drama performances.

- Expansion of tourist product with supermodern tourist infrastructure, like modern convention centers and theatres with relevant hotel substructure, cultural areas, tuned up to natural and cultural municipal environment.

- The exploitation of worldwide brand name archaeological places hosting ancient theatres (Epidaurus, Delphi, Ancient Elis next to Olympia, Philippi Macedonia e.g.) so as the whole area can be enlarged to be a global touristic and cultural destination

- Researchers and students' attraction towards universities in order to develop research and study of ancient tragedy (theatrical and classical studies).

- The ancient tragedy application as means of therapeutic practice (psychology and psychotherapy) according to Aristotle catharsis.

- The organization of conventions and seminars with main theme the ancient tragedy in remote areas of Greece.

- Enactment of more contests and festivals. A good example of this could be the International Festival of Greek Ancient Drama (it is noted that the $22^{\text {nd }}$ organization of the International Festival of Greek Ancient Drama was included in the commemoration of the European year of Cultural Heritage of 2018).

- The reinforcement of voluntarism so as to enable festivals and events to be best organized.

- The advance booking of tickets in an international basis.

Ismagilova et al., in [14] claim that "Thanks to tourist expenses additional money comes to a city economy. Growing number of tourists in region undoubtedly cause increase in production of a tourist products, creation of the active consumer market in the tourist center and growth of investment appeal of the local tourist industry". Touristic industry has always been aiming to direct touristic view knowing how tourists think of organizing their trips based on symbolic prospects.

\section{Literary Tourism - Case Study: Skiathos of Papadiamantis and Corfu of Theotokis}

The literary tourism is a kind of cultural tourism and refers to a certain category of tourists who travel especially in order to visit the places where the heroes of their books lived and wondered. That's how they experience the journey to their lovely literary world of their heroes. The place where their lovely stories of the book took place, the place where the writers where born and lived, there last habitats as well as the places the writers' imagination created are the tourists' destination for their literary plumage [13].

This sort of tourism is of particular importance for a country because it can be during the whole year and contributes substantially to the expansion of tourist period. A literary tourist chooses the country 
of his destination by himself without the suggestion of a travel agency. He is a tourist of higher educational level, ha has higher income, he spends 10 up to $15 \%$ more each day during his stay and he is a cultural tourist with a certain goal [2].

London is the first literary destination in the world where as New York, Paris, San Francisco, Rome and generally the Italian cities follow [46]. Charles Dickens (1812 1870 ) is one of English writers whose name is connected with the rapid development of literary tourism in London. This works has great readability 200 years after his birth and have been made countless serials and films. The depicts social issues and he has the ability to create vivid literary descriptions of places and situations [13].

In regard to Greece the studies have drawn the following conclusion. The decade of 1880s is suddenly characterized by the writing of many literary works. A phenomenon which may firstly have to do with the industrialization and secondly with the publication (either daily or periodical). Finally, the movement of "demotic" language and the growth of folklore are connected with that phenomenon. The competition in the magazine "Estia" for Greek short stories about the life in a village and local tradition cause the beginning of such writing. The tendency of the Modern Greek prose is called "ethnografia" and begins just after 1880 [32] and lasts until the first decades of the $20^{\text {th }}$ century.

The choice of A. Papadiamantis and K. Theotokis isn't arbitrary or an outcome of a literary acrobatism [30]. There's "common sense" [31] that the development of the Greek prose such as it is towards the end of $19^{\text {th }}$ century and in the beginning of $20^{\text {th }}$ century connects the writer from Skiathos with the writer from Corfu in regard with the subjectmatter of their works. The "Ethography" is only a step [45] for A. Papadiamantis. The writer rarely remains in the limits of "Ethnography". He quite always goes further either to social or psychological researches. Respectively in the beginning of $20^{\text {th }}$ cent. K. Theotokis receives the ethnographic tradition and without eliminating it, he substantially revives it with social orientation and realistic writing. There's also another reason for the choice of them. I believe that they reflect socio-politically the uncertain course of the Greek society on the threshold of the new century. The declining rural society of "Murderess" gives its place to the suburb "Mantonki" and to the upcoming laboring class in "Honour and Money". The social situation at that time with the industrialization to a small scale and the economy, even restricted, provides both writers with much material [39].

The "Murderess" is edited in 1903, six years after the protest in "Goudi" (1909). The disturbance is all over the Modern Greek society. The financial bankruptcy in 1897 and the International Economic Control (I.E.C.) make the Greek society suffer. All people get to realize that the old structures of their society are out of date and cannot deal with the demands of the time. However, they are not able to define sufficiently the new that will make the Greek conscience grow [56].

In literature the poem "The Twelve Lays of Gypsy" (1907) written by K. Palamas reflects it. The words of the prophet in the $8^{\text {th }}$ "speech" keep the eschatological mood without expressing the demand for some social interference. The "Honour and Money" begins to be being written in 1911, partially published in "Nouma" in 1912 (Aug - Dec) and edited in 1914. Many things have changed in Greece. The middle class with E. Venizelos as representative is simply in power founding the rules of law and the first regulations on working pay and conditions. The socialistic ideas penetrate the Greek society. G. Skliros publishes "Our Social Issue" (1907), a first attempt for a Marxist approach to interpret the Greek society. The book caused strong reaction and debate. At the same time many men of letters, social-democrats, who were called "Sociologists" formed the "Sociological Company" led by A. Papanastasiou. The following parallel reading refers to the four, successive and basic levels: a. ethnographic, b. social, c. psychological and d. human activity in certain situations. The setting in both texts is the Greek province. 
According to Papadiamantis and Theotokis the life in the Greek province is neither idyllic nor pure: the characters (Andreas, Siora Epistimi, the uncle of Andreas and Hadoula) are nether innocent nor guileless. On the contrary they seem to be without illusion, with knowledge, truth and psychographic ability. The small society of Skiathos with extreme poverty and trading is not essentially different from the poor seaside suburb in Corfu. The description of the house of Fragogianou [29] and that of Siora Epistimi [50] shows explicitly their financial situation. The external ethnographic setting is not basically different. In that setting and because of it the characters take their social part. Fragogianou during all her lifetime (Papadiammantis A. "The Murderess") and Siora Epistimi worked for their children and husband [50]. In their case what is of great importance is not only the pressure that their social role exerts upon them but also the pressure they receive as women. A situation which is easily seen as their social status is very low. The heroine of A. Papadiamantis as well as Siora Epistimi may be considered not only extreme but also unconventional persons. Hadoula deliberately refuses the basic values of the society she belongs to (the infanticide is an extreme but not the only sign of her refusal) and stays out of them.

The unconventional identity of Siora Epistimi and of Andreas is connected with the way of production because for Siora Epistimi the labor does not just satisfy a necessity but it's a way to satisfy need beyond her. On the other hand, the "labor" for Andreas is on the financial fridges of the society. Without difficulty more marginal characters can be distinguished (Trinkoulas, the Uncle of Andreas, Mitros or Moros) the son of Fragiogianou who is in prison in Halkida, accused for murder.

The psychological outline of the heroes in both works takes from easily. Their world consists the social elements of simple, poor, deserted, humiliated and contempt people. Characters perplexed with the cruel controversies of life, they are not in a position to rely upon themselves (except for Rini) and overcome these controversies and find a new moral, serenity and calmness, in other words a new balance between the urge of desire and goals they have. Our heroes sometimes have to fight against the metaphysical evil, the sin and temptation [29] and sometimes against the social evil and injustice [50] which is also a part of the evil of their life [45]. At heart the issue is the same in both works: the degraded status of a woman in the Greek society of the time: "The life is wasteful, in vain and burdensome" [29] for Fragogianou and the continuation is unbearable and incomprehensible. She either has to yield to the human destiny on the revolt and give (in her opinion) an end to the suffering that derive from her female nature [29]. "She exists to torture us and to be tortured" [29] she says for her sick young granddaughter. Besides her usual wish for young girls is "May not live... may not go further". In this way Fragogianou attempts to repair "the nature and society". She fixes the life in that way and shaves the poor from their bad luck. She can see far away, she can understand, she can give relief... She becomes the Judge, "the God" [41]. The secret signs she looks for justify her decision and goes on with her job. However, the noose tightens firmly around Hadoula and the old Hadoula meets the death in the middle of the road leading from punishment to redemption.

K. Theotokis strongly and perceivably attempts to present his heroes more dependable upon the conditions of their society and financial life. There's a general attitude to them. They destroy and get destroyed. Siora Epistimi, Andreas his uncle, Trinkoulos all they wish their weakness and malice led by the money and passion. The only positive character is Rini, who endures her misfortune sending away Andreas. Even though she knows that she'll suffer she doesn't succumb. Her own revolution is the demand for a right for a job and a right in society. Her decision points out the role of a job in freedom. "I am a labourer, who am I in need of?" [50] and expresses a redeeming reaction against the established society and mentality. 
The parallel reading of these two works points out the dialectical complementarity. Both writers have a common starting-point. Beginning from ethnography they lead the story towards a systematic search to get out of the ethnography itself [56]. It's not wrong to say that both Papadiamantis (to a less degree) and Theotokis use to the utmost the limits of ethnography. The characters of their heroes along with the development of naturalism in Greece, sometimes come to completion and sometimes collide with society (Hadoula), sometimes are defeated on personal level (Rimi) but they give a positive prospect.

Papadiamantis (Murderess) choose an advance fantastic solution giving his hero a tragic aspect and maybe a metaphysical character. On the contrary Theotokis (Honour and Money) in a strict realistic way shows the way that leads a woman to social liberation. The revolution of the heroes in any case is clear as well as their independence which finally associates their freedom with the action of judgement. From a common perspective the dramatic leitmotif about the characters of both writers is accomplished. "The old Hadoula met the death in the passage... in the middle of distance from derive to human justice". Such death cannot be considered to be either as a punishment by human justice or redemption in front of derive justice. Papadiamantis neither judges nor condemns. He understands the gradual deterioration and distortion of a human character but he keeps being there. In a parallel way Theotokis mores. His characters are fatal and irresponsible victims of a social system based upon the injustice. Their strain situation is due to an apparent contradiction. "All suffer but nobody is responsible by himself". From such an angle both texts include their social service. Both A. Papadiamantis and K. Theotokis (each one from his own perspective) are sensitive individuals who undergo the social events of their time. Their social speech reveals their social perspective. No one can write without reading audience and fable without a definite audience that the historical circumstances oreated, without a fable that depends to a great degree upon the demands of that reading audience [39].

If this aspect is accepted then the terminology "engaged literature" -at least for the case of A. Papadiamantis- even if it seems to be strange, can be applied to both texts [40].

Both writers are engaged with their readers in the same social adventure and being as well in the same society they talk about them, they talk about themselves and talking about themselves they talk about the others. The above reference is more acceptable for A. Papadiamantis. However, we should not forget $\mathrm{K}$. Theotokis' strong moral attitude esp. towards the end of this life (1919-1922).

Greece generally needs a more integrated scientific analysis of the tourist object [17] and as it shows so far for literally tourism we abstain so much from European and national markets. Only Tinos since 2010 has the privilege to be the island of an important literally festival in Greece with 120 writers with world recognition from all continent, with an initiative and third try of Ntinos Siotis from the society of De (katon) and in association with topical entities of Tinos (www.efsyn.gr).

We quote the texts of the research as a sample of our literature in a corresponding time with the writer of England who is claimed to be a magnet of literally tourism in his country. Skiathos of Papadiamantis and Corfu of Theodokis with "Murderess" and "Honour and Money" respectively are writing and force and acceleration full of concepts and vivid pictures. They are not definitely inferior to the English writings that fed to the explosion of the literary tourism in London. At the same time, the bibliographic research shows that literary tourism has made efforts to show the island through local associations and individuals who have been allured by the island and Papadiamantis.

It's of great importance particularly G. Koumentakis attempt together with "Lyric Scene" to transform Fragogianou into a tragic operatic protagonist in a literary gathering which was an event of great success and promotion. Minon Michailidis, the art director, commented a little later that the 
psyche of Fragogianou wandered and was expressed unhindered and freely, reaching the point that reason couldn't have reached. The nature and Fragogianou have the first role in opera whereas Skiathos has the second one. The nature is around Fragogianou, it surrounds her, it suffocates her and is lost between divine and human justice [48].

In an attempt to be the touristic island shown and promoted through literature:

1. The area was literary mapped (www.academia.edu)

2. There is a digital map with the literary names of the places in Skiathos (www.paki.webpages.auth.gr)

3. Literary Geography depicts Papadiamantis text

4. House Museum with the writer's items

5. The central pedestrian street named after the writer

6. Best of Papadiamantis near the school he attended at early age

Skiathos continues to be a source of inspiration and a non-seen before worship has arisen in theatrical stages of the world. Skiathos of 60 s became the scene for the next production of National Theater with the play "Sunset at the Villa Thalia" by Alex Kagie Cambel, with Greek and foreign actors.

Respectively in Corfu, the village Kourousades in Theodokis in a place of particular natural beauty surrounded by olive groves and cypress trees and superb beach and alluring view over Ionian Sea. The tower of the Theodokis or else Kourasades is the house where the father of Corfu novel and the creator of social literature was born and died. Unfortunately, it has not been done anything for the house museum to be preserved. In 1884 the movie "The price of love" was shot based on the play of Elena Kerandrou "The price and the money". The film won 7 state awards in Thessaloniki [48] and was presented again in 2018 with reference for the national day of women at the town hall of Kaisariani. The critics at Athinorama gave her 3.5 stars and it cut many tickets.

The cultural association of Kourasades believe that this happens due to the self sufficiency that Corfu has always had, thanks to the natural abundance and tourism. Thus there is no need for extraversion and social show.

The literary tourism may the foundation for a multinational literary of the country and make lasting relations. Greece can be the destination of literary tourism because according to the research of the study cases our literature is alive and rich in meanings, words, pictures and of unique beauty and interest similar to those of London which is the world champion in the kind. In this context, we have some suggestions: making literary maps by the cultural associations of the areas, training local guides with financial support from local authorities, invitation to literary festivals in which the audience will participate as well as the creators and loading and showing on internet not only the works and house museums but also the life of writers of international recognition as a great opportunity for literary tourism if only the people in charge realize it and are organized for it.

\section{Conclusions}

By combining the information society and cyber-culture advantages with the classic cinematography and literature could have huge impact on the tourism industry in any country.

Angelopoulos' filmography has been an important tool of Greek touristic promotion. His films present great places and sightseeing, social life through the life of his heroes, the main actors. His films have an economic contribution promoting Greek nature biodiversity and Greek beauty. In an endless game with time (past and present) he discusses historical topics in a unique way. The Greek places (Florina, Prespes, Ioannina etc.) encourage cinematic tourism, attracting tourists from all over the world. His films also promote alternative tourism by showing nature (birds, insects, animals, culture, customs, tradition etc.). These are integral elements that compose the journey of his filmography and alternative tourism. His movies managed to attract thousands of spectators and tourists. 
Ancient tragedy born in Ancient Greece has always been considered the most important cultural heritage of all Europe. In this paper it was shown the major issue of tourist attraction through ancient drama. Also according to modern scientific literature Touristic policy is based on publicity, sensitization of people worldwide, on common policy in municipalities and communities, on reinforcement good practice of cooperation.

In order to achieve that goal certain difficulties and obstacles have to be surpassed mainly emphasizing on able schedules, programming, and quick peripheral and local organization.

These actions should take into account all related cyber-culture technologies, from Web, social media, streaming to video games, virtual reality, and augmented reality.

\section{References}

[1] Alexandri, E. (2015) Cultural heritagemanagement, Athens, Ion, Publications.

[2] Andriotis K. 2008, "Euphoria and alternative tourism", Stamoulis, Athens

[3] Cartwright, M. (2013) 'Greek tragedy: Definition. Ancient History", Encyclopedia available from http://www.ancient.eu.com/Greek_Trage dy/ Accessed 3 February 2104.

[4] Cheong, S. M., \& Miller, M. L. (2000). Power and tourism: A Foucauldian observation. Annals of Tourism Research, 27(2), 371-390.

[5] Ciment, M., \& Tiercant,H.(1989). Theo Anghelopoulos. Paris.

[6] Croy, G. \& Heitmann, S. (2011). Tourism and Film. In: Research Themes for Tourism (eds. P. Robinson, S. Heitmann and P.U.C. Dieke) CAB International.

[7] Dimopoulos M, Liappa M.F. (1974), Modern cinema, Athens

[8] Dr. Nikolaos Boukas, Dr Vassilios Ziakas, Dr Georgios Boustras, "Olympic Legacy and Cultural Tourism: Exploring the Facets of Athens' Olympic Heritage", ed. Center for Sustainable Management of Tourism, Sport \& Events.

[9] Elitis Od. 1996, «The magic of Papadiamantis», Ypsilon, Athens Foley,
H. (2003) 'Choral identity in Greek tragedy'. Classical Philology, 98(1), 130 .

[10]Foley, H. (2003) ' Choral identity in Greek tragedy'. Classical Philology, 98(1), 1-30. Felsenstein, D. \& Fleischer, A. (2003). Local Festivals and Tourism Promotion: The Role of Public Assistance and Visitor Expenditure. Journal of Travel Research, Vol. 41, May 2003, 385-392

[11]Felsenstein, D. \& Fleischer, A. (2003). Local Festivals and Tourism Promotion: The Role of Public Assistance and Visitor Expenditure. Journal of Travel Research, Vol. 41, May 2003, 385-392

[12]Horton, A. (1999). The Films of Theo Angelopoulos: A Cinema of Contemplation. Princeton University Press.

[13] Ioannou R, 2016, "Literary tourism in New England", www.wordstocount.com

[14] Ismagilova, G.N. Safiullin, L.N. Bagautdinova, N.G. (2014). Tourism development in the region based on historical heritage. Life Science Journal $2014 ; 11(6 s)$

[15]www.academia.edu, "hartografontas ti skiatho tou Papadiamanti"

[16] Kosmidou, S.E. (2017). Theo Angelopoulos's $O$ Thiasos/The Travelling Players (1975) and Oi Kynigoi/The Hunters (1977) and how they affect the Brechtian Project. University of Sheffield.

[17]Laloumis D., Roupas V.,1998 Tourism and Departure Management, Stamoulis, Athens

[18] Lazou A, (2004), "Orchesis: texts on ancient greek dance' 'Athens, ed Ways of Life.

[19]Lazou. A. \& Mastora, I. (2017) 'Orchesis \& Athletism, Texts of History Philosophy amd Pedagogy', Arnaoutis pbs, Athens

[20]Loukia M, Kotsaki A, (2014)' Ancient Greek Drama and its Architecture as a means to reinforce tourism in Greece', Procedia - Social and Behavioral Sciences 148 (2014) $573-578$.

[21] Martin, M. (1974), The cinema language, 
Athens, Kalvos Publications.

[22] Mastora, I., Manola, M., Nikolaidi, A."National touristic promotion via ancient drama", journal of Tourism Reserch, volume 21, December 2018

[23] Micciche,L.Jordan,1.(1982) il materialismo estetico di T Anghelopoulos in cinemasettanta» v. 113 ,Febbraio 1977.

[24]Mitchell, H and Stewart, M. (2012). Movies and holidays: The empirical relationship between movies and Tourism'. Applied Economics Letters, vol. 19, no. 15, pp. 1437-1440.

[25] Mitsis, X. (1998), As you love cinema vol. 92.

[26] Moreau, J. Ganz, B. Angelopoulos, T. (1991). The Theo Angelopoulos Collection, Vol. 3 DVD Series

[27] Ministry of Tourism-Greek National Tourism Organization (2007) The Greek Poster - a journey in Time through Art, Athens.

[28] www.megaron.gr.2016,

George

Koumentakis: i fonissa-megaron_mousikis (09/01/2019)

[29] Papadiamantis A.,2001, "The Murderess", Athens, Edition "Sichroni epoxi"

[30]Pazanos G. 1984, The analysis of a narrative "Honor and money", Journal "Diavazo" Volume 22

[31]Mpalaskas K. 1979, Journal "Nea Paideia",Volume 10

[32]Politis N., www.lib.auth.gr, Politis N,'s collection., Library of Arisrotelio University

[33]Rafaelides, B. (2000) For Salonica festival of cinematography, Egokeros Publications.

[34]Rafaelides, B. (2003) Trip to myth. Egokeros Publications, Athens.

[35] Rafaelides, B. (1980-1987). Cinema issues. Egokeros edit, Athens, vol. 4.

[36] Rafaelides, B. The foggy place of history.

[37] Riley, R.W. \& Van Doren (1992). Movies as tourism promotion. A 'pull' factor in a 'push' location. Tourism Management September 1992, pp. 268-274.

[38]Riley, R., Baker, D., and Van Doren, C. S. (1998) "Movie induced tourism",
Annals of Tourism Research, 25, 919-235.

[39] Sahinis A., 1973,"The modern Greek novel", Edition "Estia"

[40] Santre J.P 1971, "What is literary?", Traduction by Athanasiou, Edition "70"

[41] Saranti G. 1981, "Tribute to Papadiamantis and to his world",Edition Triantaphyllopoulos, Athens

[42] Skoultsos. S. (2014) "The potential of festivals and their contribution to culture and tourism", Greek Economic Outlook of Planning and Economic Research.

[43] Stathi E..(2012). Collective work Festival of cinema in Salonica.

[44] Stathi E. (1996) Place and time in cinema of T. Angelopoulos. Panteion University.

[45] Stergiopoulos K., 1979, "Papadiamantis in our days; twenty texts for his life and his work", "Edition of friends"

[46] Stergiou A. 2018, "Literary tourism; a market where Greece abstains", www.agropost.gr

[47] Tavakolia R., Muraab P., Netnography in tourism - Beyond Web 2.0, Annals of Tourism Research, Volume 73, November 2018, Pages 190-192

[48] Tabaki A., www.athensvoice.gr, Koumentakis, Svolos, Efklidis at Lyric Scene

[49] Theotokas G., 1979, "Free spirit", Edition "Ermis", Athens

[50] Theotokis K., 1993 "Honor and money",Edition "Nefeli"

[51] Tsartas.P. Lytras, P. (2017) Tourism, touristic development, Athens, Papazisi Publications.

[52] Vagionis N. \& Loumioti, M. (2011). Movies as a tool of modern tourist marketing. Tourismos: an international multidisciplinary Journal of Tourism

[53] Valoukos, S. (2011) New Greek cinema (1965-1981). History and politics. Egokeros Publications.

[54] Vassiliou, T. (2017). The Cinema of Theo Angelopoulos edited by Angelos Koutsourakis \& Mark Stevens. Book Review. FILMICON: Journal of Greek Film Studies Issue 4, December 2017.

[55] Volume 6, Number 2, autumn 2011, pp. 353-362. 
[56] Vitti M. 2008," The history of modern Greek literary", Edition "Odusseas", Athens

[57] Yutkevicz, S. (1983). Models of political cinematography, Athens, Sichroni epochi, transl, Prokou, L.

[58]Winnert, D. (1997) 100 years Greek films, (from 1897 until today). Maniateas Publications, Athens.

[59] Winter, T. (2002) ' Angkor Meets Tomb Raider: setting the scene" International Journal of Heritage Studies, Vol. 8, No. 4, 2002, pp. 323-336.

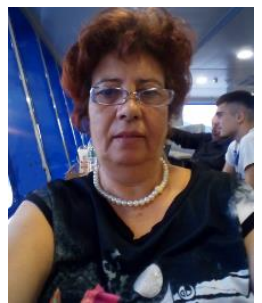

Dr. Maria MANOLA is assistant professor at the Department of Tourism Management, University of West Attica. She has been working for 25 years in the Tourism Management Department of the University of West Attica. She teaches Italian language for tourism and literary and cultural tourism. She has published papers in various journals in the field of culture, tourism and also interdisciplinary. 